\title{
A renewable chemistry linked to the Brazilian biofuel production
}

\author{
Sílvio Vaz Jr
}

\begin{abstract}
The transition from the current dependence on non-renewable raw materials to biomass as an oil substitute has become a strategic challenge to the twenty-first century. Chemicals have the highest potential to add value on a vegetable biomass chain because of the importance of conventional chemical industry and fine chemical chemistry for different sectors of economy, highlighting compounds that may be used as building blocks, intermediates of synthesis and specialties. This review deals with the economic potential of residual biomass from biodiesel and bioethanol industries as a source of raw material to support the production of renewable chemicals. The focus is on illustrating the perspectives and challenges for the development of a Brazilian renewable chemical industry, considering that Brazil is one of the largest global producers of agro-industrial biomass for several purposes, especially for biofuels.
\end{abstract}

Keywords: Biofuels industry; Green chemistry; Biorefinery; Bioeconomy

\section{Introduction}

Biorefining and green chemistry are two concepts that focus on sustainable utilization of biomass creating value chains similar to those derived from the petroleum derivatives. There is a great synergy between the biorefineries and green chemistry, mainly regarding to minimisation of residues and environmental impacts for the creation of a green economy or bioeconomy [1,2]. Therefore, the concepts of biorefining and green chemistry combine to create less impact on environment and comprise integrated sustainable systems (raw material, process, product and residues) according to technical parameters which take into account, among other aspects, the energy and mass balances, the life cycle analysis, and the application of practical principles to promote best practices for $R \& D$ and production processes $[3,4]$.

In terms of economic valorization [5], fine chemicals developed from biomass resulting from biofuel production have significant potential to generate additional revenue because of their strategic participation in the chemical industry which can be used as both inputs and final products in sectors such as pharmaceutical, automotive, construction, agribusiness, cosmetics, etc. Biofuels and

Correspondence: silvio.vaz@embrapa.br

Embrapa Agroenergy, Parque Estação Biológica, Av. W3 Norte, Asa Norte, Brasília/DF, CEP 70770-901, Brazil materials are a second baseline of valorization, followed by energy and bulk chemicals or input chemicals, such as fertilizers and agrochemicals. In Brazil, efforts have been made to evaluate the economic potential of biomass to support the development of sustainable chemistry. On the other hand, we can verify a lack of studies linking possible profits from biomass in bulk chemicals, with the exception of those related to second generation ethanol (2G ethanol) and use of vinasse for soil fertilization [6,7]. It is important to highlight that when it comes to biofuels, generating revenue from residual biomass is paramount to enable a reliable, economic productive process, with environmental and social gains [8].

The global market for chemical products is estimated at US $\$ 100$ billion per year, from which $3 \%$ are related to bioproducts, or derivatives of biomass. It is expected that the production of biobased chemicals will have increased substantially by 2025 [9]. The increase in the demand for bio-derived chemical not only offers a great number of opportunities for green technologies, and processes which use residues in biorefineries, but also presents several challenges related to market prices and replacement of non-renewable products. Currently renewable materials is around $25 \%$ and it is expected to increase to $50 \%$, and the current $10 \%$ participation of polymers may reach $20 \%$ [10].

\section{穴}


In this article, we discuss the economic potential from renewable chemistry allied to biofuel production to contri bute to the creation sustainable chemistry in Brazil.

\section{Review}

\section{Residual biomass from biofuel production: a cheap} feedstock source

Firstly, we need to define residues as surplus materials from a productive process, of low or no economic value. The main residues from biofuel production (biodiesel and bioethanol) are (i) lignocellulosic materials (bagasse, straw, fiber, bark, etc.), (ii) residual sugars or the ones with high content of impurities, (iii) residual olefinic lipids or also the ones with high content of impurities, and (iv) other types that are a mixture of the first three, such as residual biomass after vegetable oil extraction referred to as cake, which in the case of soybean cake can be directly used. Other sources of cake, such as castor bean and jatropha, contain toxic compounds such as ricin and phorbol esters, which limit their use for feedstock $[11,12]$.

Since plants can contain high amounts of lignin (18\% to $35 \% \mathrm{w} / w)$, cellulose (40\% to $50 \% w / w)$, and hemicellulose
(10\% to $35 \% w / w)$ [13], lignocellulosic residues are considered as one of the most promising sources of industrial raw material. In general, the final evaluation of the potential depends on a number of factors such as the processing plant, the quantity biomass and rate at which the residue is produced, environmental legislation, cost reduction, etc. An increase in the production of biodiesel and bioethanol will lead to an increase in the amounts of the residues generated $[14,15]$. Therefore, this review will discuss the Brazilian bioethanol and biodiesel industry because, similarly to petrochemical industry, other use of by-products are very important for the economic establishment of a biofuels sector.

\section{Bioethanol production}

Brazil produces around 588.5 million tons of sugarcane (Saccharum spp.) for bioethanol and sugar production [16]. Around $28 \% w / w$ of the total sugarcane biomass produced in Brazil ends up as bagasse, resulting in an estimated production of 169 million tons/year [17], which is the residue with most economic potential, followed by straw - $140 \mathrm{~kg} /$ ton [18] and vinasse - approximately 10 to $15 \mathrm{~L}$ for each liter of ethanol [19].

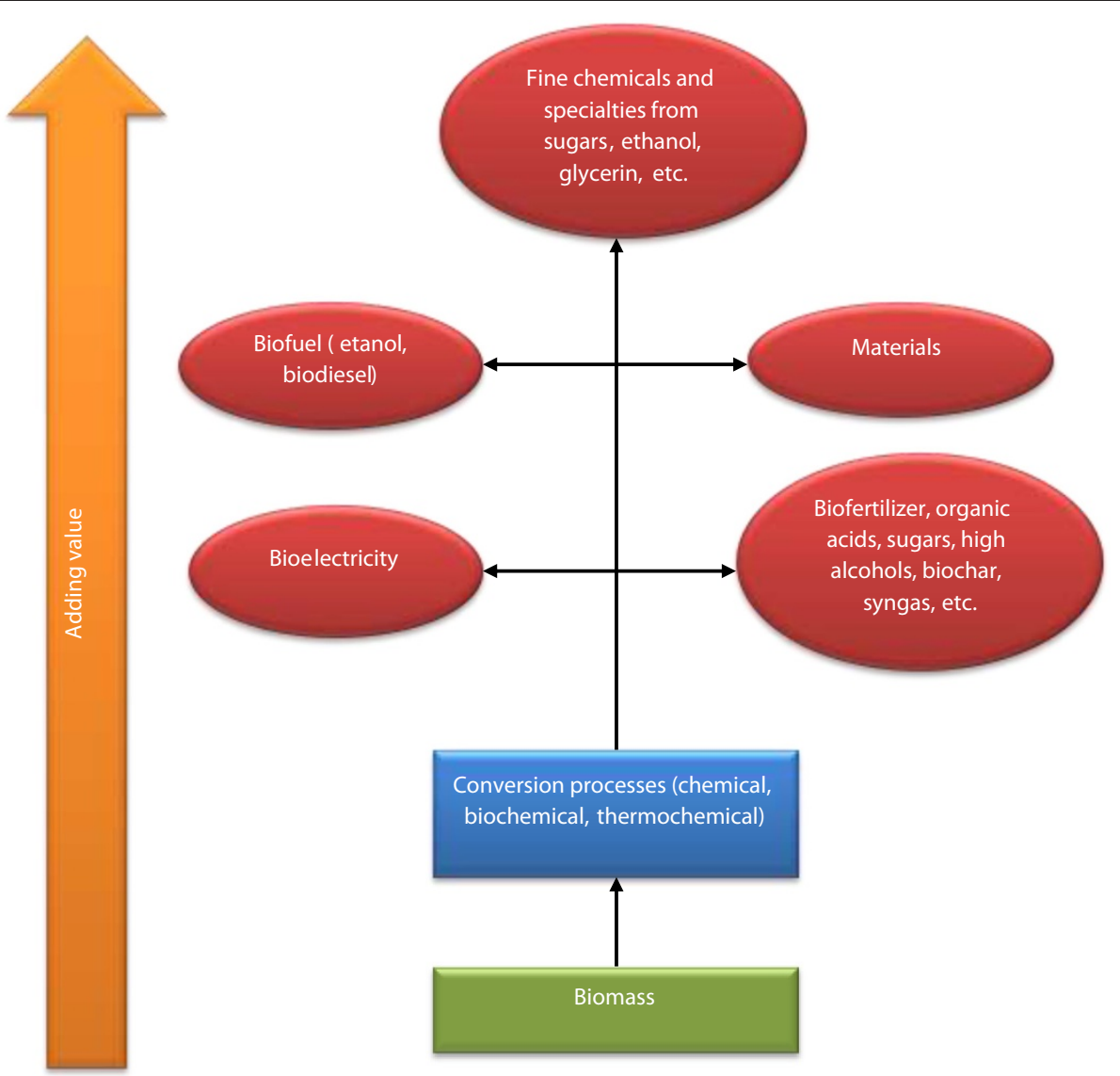

Figure $1 \mathrm{~A}$ proposal for integration of production between renewable chemistry and agro-industry. 
Sugarcane bagasse is already used for heat and electrical power generation, thus providing sugarcane companies self-sufficiency in electricity power production and means to sell the surplus to the national grid [20]. The use of bagasse and straw for $2 \mathrm{G}$ ethanol production is a subject of a large quantity of published papers, but there is not yet an established commercial production. Furthermore, there are some relevant barriers to be overcome, such as reduction of enzymes costs and development of yeast strains, which ferment pentose from hemicellulose polymeric structure [21]. Vinasse has been used for biogas generation as well as fertilizer. However, the use of vinasse as fertilizer requires frequent monitoring, due to the high content of ions and organic matter, that may alter the physico-chemical properties of the soil, with subsequent leaching of ions such as $\mathrm{NO}_{3}^{-}, \mathrm{PO}_{4}^{3-}, \mathrm{K}^{+}$, etc., and pollution of groundwater. Vinasse has also a great potential to pollute surface water when it is discharged directly in the water bodies [22].

\section{Biodiesel production}

Biodiesel production involves the use of oleaginous plants such as soy beans (Glycine max), oil palm (Elaeis guineensis), cotton (Gossypium spp. L.), sunflower (Helianthus annuus), castor bean (Ricinus communis), macauba palm (Acrocomia aculeata), and jatropha (Jatropha curcas). The last two are still under evaluation as for their agronomic potentials. Animal fat is also an important raw material for biodiesel, but it is not taken into account in this review because of the vegetable biomass issue.

Biodiesel production generates large amounts of lignocellulosic residues which are derived from the crushing and extraction of oil plants that also produces aqueous effluents. Nowadays, soybean is the main raw material in use, with a total grain production of 81.6 million tons and a biodiesel production of 2.9 million $\mathrm{m}^{3}$ [23].

Animal feed may be obtained from the remaining lignocellulosic biomass (bunches, barks, fibers, etc.) after extraction of oil. Furthermore, these residues can be applied for soil recovery, as source of organic matter that is expected to improve soil phisico-chemical properties [24]. The production of polymeric materials is another potential application under development, mainly as derivatives of the cellulose structure such as nanofibers [25]. Large efforts are devoted to remove toxic compounds from jatropha seed cake in order to promote its use as a protein source for animal feed [26].

Palm oil mill effluent (POME), which is the aqueous effluent of biodiesel production from palm, may be used for biogas production (mainly a methane gas) in anaerobic biodigesters [27]. Each ton of crude palm oil is estimated to produce $2.5 \mathrm{~m}^{3}$ of biogas [28]. POME is also a suitable feedstock to support synthesis of biopolymers such as polyhydroxybutyrate (PHB), through fermentation processes [29].

Glycerine is the main co-product of biodiesel production and is currently used in great quantities by the healthcare and pharmaceutical industry for cosmetics formulation, shampoos and soap bars. However, glycerine has a high cost of purification when it is used in pharmaceutical and cosmetic applications. Nowadays, there is a great surplus due to the increase in the biodiesel production. In fact, nearly $100 \mathrm{~m}^{3}$ of biodiesel results in $10 \mathrm{~m}^{3}$ of glycerine $(10 \% w / w)$, with an estimation of Brazilian glycerine production of $275,000 \mathrm{~m}^{3}$ from 2.7 million $\mathrm{m}^{3}$ of biodiesel production that may become an environmental problem without an industrial use [30]. The development and application of chemical catalysts continues to be fostered to enable the production of chemical commodities, polymers, and fuel additives from glycerol.

\section{Technologies used}

In this review, we consider chemical and biochemical technologies, as well as thermochemical technologies of conversion processes. Despite efforts from institutions like US Department of Energy - National Renewable Energy Laboratory (DOE-NREL) in R\&D\&I for products and potential routes, the majority of the green compounds that may be obtained from biofuels residues have not reached industrial potential yet. A good example is succinic acid, considered as one of the main opportunities for renewable chemistry due to its many potential applications as a chemical building block [31]. Unfortunately, the number of consolidated processes is limited for its production at industrial scale [32].

In this context, it is important to evaluate each molecule stemming from biofuel production processes in relation to the Brazilian economic scenario. First of all, Brazilian chemical industry imports large amount of high value compounds, e.g., building blocks, intermediates and specialties for chemistry and fine chemistry, not having developed a suitable technology that may revert this trend. The consequence is that the Brazilian chemical industry has a trade deficit of US\$ 28.1 billion [33]. Second, the need of developing synthesis of intermediates, mainly for drugs, may become more interesting than the search for building blocks, contrary to what is seen in the international scenario. Table 1 presents comparative production data about the main renewable agro-industrial chains in Brazil, except food, against the same worldwide production evidencing the favorable position in the global agribusiness scenario. Table 2 describes some target compounds with high potential for the renewable Chemistry in Brazil, which are closely related to the development of a chemical (e.g., chemo-catalytic), biochemical (e.g., biocatalytic and fermentation), and thermochemical (e.g., fast pyrolysis and gasification) technology for more 
Table 1 Comparative production data from Brazilian renewable agro-industrial products against the same worldwide production [34]

\begin{tabular}{llll}
\hline & \multicolumn{3}{c}{ Usages } \\
\cline { 2 - 4 } & Biofuels & Natural fibers & Paper \\
\hline Worldwide & $\begin{array}{l}1.1 \text { million of ktons } \\
\text { of oil equivalent }\end{array}$ & 28.1 million tons & 210.7 million tons \\
Brazil & $\begin{array}{l}\text { 46 thousand of ktons } \\
\text { of oil equivalent }\end{array}$ & 1.3 million tons & 4.3 million tons \\
\hline
\end{tabular}

efficient and environmentally friendly conversion processes. In fact, from Tables 1 and 2, we can infer the great Brazilian potential for a renewable chemistry, with a large contribution from biomass residues as a renewable source of raw materials.

\section{Brazilian scenario for a renewable chemistry}

Chemical processes for biomass conversion in Brazil are mainly related to ethanol derivatives production, sucrochemistry, and oleochemistry. As one of the largest worldwide sugarcane and soybean producer, a renewable chemistry based on saccharose, ethanol, and vegetable oil was developed, with an important economic role. Nowadays, Brazil produces 38.2 million tons of sugar (saccharose), 23.2 thousand $\mathrm{m}^{3}$ of ethanol (anhydrous and hydrated) [16], and 7.1 million tons of soybean oil [23].
Part of this production is used in the chemical industry to obtain fine chemicals, polymers, and specialties $[47,48]$. Unfortunately, Brazil had a decrease in its production of renewable chemicals from ethanol in the last decades that is to be related to renewed activities of the petrochemical industries and their more attractive prices [49].

In some cases, the price and performance of green chemicals are comparable to that of petrochemicals. For example, ethene from petroleum has compromised the development of a related market because the price of the corresponding green chemical is higher. A typical Brazilian case is the green polyethylene produced by Braskem from sugarcane.

The development of building blocks and intermediates from catalytic routes, mainly from sucrochemistry, is the object of much research in Brazil and receives supported by the São Paulo Research Foundation (FAPESP) [50], the Funding of Studies and Projects (FINEP) [51], and the Brazilian Development Bank (BNDES) [52].

The fact that Brazil is a large producer of sugar makes this material the main source of precursors for biochemical processes, mainly fermentation. Furthermore, Brazil highlights the potential of renewable chemistry via the production of Braskem polyethylene from ethanol, a green plastic polymer used for bag production [53]. Furthermore, synthetic biology has received attention

Table 2 Target compounds from residues and co-products with high economic potential for a Brazilian renewable chemistry

\begin{tabular}{|c|c|c|c|c|}
\hline Target compound & Precursor & Route & Status & Ref. \\
\hline Acrylic acid & Glycerin & Organic synthesis & In development: improvement of catalysts, yield, others & {$[35]$} \\
\hline 2,5-Furandicarboxylic acid & $\begin{array}{l}\text { Glucose from } \\
\text { celullose }\end{array}$ & $\begin{array}{l}\text { Organic synthesis } \\
\text { Fermentation }\end{array}$ & $\begin{array}{l}\text { In development: improvement of catalysts, biocatalysts, } \\
\text { micro-organisms, yield, others }\end{array}$ & {$[36]$} \\
\hline Succinic acid & $\begin{array}{l}\text { Xylose from } \\
\text { hemicelullose }\end{array}$ & Fermentation & In development: improvement of micro-organisms and yields & {$[37,38]$} \\
\hline Fuel additives & Glycerin & Organic synthesis & In development: improvement of catalysts, yield, others & {$[39]$} \\
\hline Antioxidants & Lignin & Catalytic cracking & In development: improvement of catalysts, yield, others & {$[40]$} \\
\hline $\begin{array}{l}\text { Derivatives from celullose } \\
\text { (acids, esters, nitrates, eters, etc.) }\end{array}$ & Celullose & Organic synthesis & Established industrial processes & {$[41]$} \\
\hline \multirow[t]{2}{*}{ 2G ethanol } & $\begin{array}{l}\text { Glucose from } \\
\text { celullose }\end{array}$ & Fermentation & $\begin{array}{l}\text { In development: improvement of enzymes, micro-organisms, } \\
\text { yields, and cost reduction }\end{array}$ & {$[42]$} \\
\hline & $\begin{array}{l}\text { Xylose from } \\
\text { hemicelullose }\end{array}$ & & & \\
\hline Phenols & Lignin & Catalytic cracking & In development: improvement of catalysts, yield, others & [43] \\
\hline Furfural & $\begin{array}{l}\text { Xylose from } \\
\text { hemicelullose }\end{array}$ & Organic synthesis & $\begin{array}{l}\text { Established industrial processes: still needing to improve catalysts, } \\
\text { yields, others }\end{array}$ & {$[37]$} \\
\hline Syngas $\left(\mathrm{CO}+\mathrm{H}_{2}\right)$ & $\begin{array}{l}\text { Lignocelullosic } \\
\text { biomass }\end{array}$ & Gasification & $\begin{array}{l}\text { Established industrial processes based on petroleum: still needing } \\
\text { to improve yields }\end{array}$ & {$[44]$} \\
\hline 5-Hydroxymethylfurfural & Celullose & Organic synthesis & $\begin{array}{l}\text { Established industrial processes: still needing to improve catalysts, } \\
\text { yields, others }\end{array}$ & {$[36]$} \\
\hline Sulfonated lignins & Lignin & Organic synthesis & Established industrial processes & {$[45]$} \\
\hline Xylitol & $\begin{array}{l}\text { Xylose from } \\
\text { hemicelullose }\end{array}$ & Organic synthesis & In development: improvement of catalysts, yield, others & {$[46]$} \\
\hline
\end{tabular}


from $R \& D$ of industry and Brazilian institutions, due to expected cost reductions related to renewable chemicals. More challenges are also visible in the fields of genetic engineering, kinetics, downstream processes, and, therefore, for an overall economic feasibility based on renewable biomass chemicals.

The second generation ethanol from non-food biomasses is considered strategic to increase Brazil's bioethanol production. Cooperative programs in this respect have been created by FAPESP, FINEP, and BNDES in order to support technology and market entry. It is expected that a national production of second generation ethanol will be started in 2014 from GranBio [54].

Thermal processing of biomass were the basis of the Brazilian economic growth for nearly 500 years because the energy was, firstly, obtained from combustion and, second, the related charcoal was used by the metallurgic industries as a reducing agent for metals in furnaces to produce alloys. Both of these uses caused large devastation of the native forests

Nowadays, Brazil produces nearly 330 million tons of agro-industrial residues [55], and large part of this can be used in thermochemical processes, such pyrolysis and gasification. Unfortunately, Brazilian thermochemical processes are not actively pursed in relation to renewable chemistry. Difficulties with thermochemical processes due to low biomass density and development of complementary processes, as the Fisher-Tropsh process, considerably inhibit the establishment of these technologies. In alternative, these processes can be usefully employed by the petrochemical industry, such as Petrobras [56]. In this respect, the Institute for Technological Research (IPT) has an already ongoing plan to construct a site in the state of São Paulo to promote the development of thermochemical technologies [57].

\section{Conclusions}

This article aimed to show the economic potential of the biofuel residues as a raw material for a Brazilian renewable chemistry, following the application of biorefinery and green chemistry concepts. A considerable economic potential is attributed to the development of high value molecules, which become synthetic building blocks, or intermediate specialty chemicals.

When evaluating target compounds considered as potentially valuable chemicals in other world regions, it is noticed that they do not always reflect the necessity of the Brazilian economy. This shows that detailed information are required from studies on the specific Brazilian conditions in order to reach the definition of a national scenario for technical-scientific planning and real development of an economic value.

The processes involved in the chemical, biochemical, and thermochemical conversion are fundamental for exploring the full potential of a Brazilian industry of renewable chemistry. Concomitantly, there is an evident need to setup strong actions to support the development of national technologies that take into account pretreatments, catalysts, micro-organisms and logistics. Despite shortcomings and uncertainties, Brazil undoubtedly presents a breathtaking scenario to convert itself into a strong global player in the field of renewable chemistry.

\begin{abstract}
Abbreviations
BNDES: The Brazilian Development Bank; DOE-NREL: US Department of Energy - National Renewable Energy Laboratory; FAPESP: São Paulo Research Foundation; FINEP: The Funding of Studies and projects; IPT: The Institute for Technological Research; PHA: Polyhydroxyalkanoate; POME: Palm oil mill effluent.
\end{abstract}

\section{Competing interests}

The author declare that he has no competing interests.

Received: 20 March 2014 Accepted: 14 August 2014

Published online: 27 August 2014

\section{References}

1. The Bioeconomy to 2030: Designing a Policy Agenda. In: [http://www.oecd. org/futures/long-termtechnologicalsocietalchallenges/thebioeconomyto 2030designingapolicyagenda.htm]

2. Philp JC, Ritchie RJ, Guy K (2013) Biobased plastics in a bioeconomy. Trends Biotechnol 31:65-67

3. Kamm B, Gruber PR, Kamm M (2010) Biorefineries - industrial processes and products: status quo and future directions. Wiley, Weinheim

4. Anastas P, Warner J (1998) Green chemistry: theory and practice. Oxford University Press, New York

5. Presentation. In: [http://www.siadeb.org/images/brochuras/BrochuraSIADEBEn.pdf]

6. Dias MOS, Junqueira TL, Cavalett O, Pavanello LG, Cunha MP, Jesus CDF, Filho RM, Bonomi A (2013) Biorefineries for the production of first and second generation ethanol and electricity from sugarcane. Appl Energy 109:72-78

7. De Oliveira BG, Carvalho JLN, Cerri CEP, Cerri CC, Feigl BJ (2013) Soil greenhouse gas fluxes from vinasse application in Brazilian sugarcane areas. Geoderma 2013(200-201):77-84

8. Galdos M, Cavalett O, Seabra JEA, Nogueira LAH, Bonomi A (2013) Trends in global warming and human health impacts related to Brazilian sugarcane ethanol production considering black carbon emissions. Appl Energy 104:576-582

9. Vijayendran BJ (2010) Bio products from bio refineries - trends, challenges and opportunities. Bus Chem 7:109-115

10. Biobased chemicals and products: a new driver for green jobs. In: [http:// www.bio.org/articles/biobased-chemicals-and-products-new-driver-greenjobs]

11. Creppy E-E, Lugnier AAJ, Dirheimer G (1980) Isolation and properties of two toxic tryptic peptides from ricin, the toxin of Ricinus communis $L$. (castor bean) seeds. Toxicon 18:649-660

12. Barahona E, Díaz P, Castellano V, Anadón A (2010) Toxicological profile by Jatropha curcas L. Toxicol Lett 196:S287

13. Hon DN-S, Shiraishi N (2001) Wood and cellulosic chemistry. Marcel Dekker, New York

14. Biofuels. In:[http://www.iea.org/publications/freepublications/publication/ Tracking_clean_energy_progress_2014.pdf]

15. Remap 2030. In: [http://www.irena.org/menu/index.aspx?mnu=Subcat\&Pri MenulD=36\&CatID=141\&SubcatID=375]

16. Unicadata. In: [http://www.unicadata.com.br/index.php?idioma=2]

17. Hofsetz K, Silva MA (2012) Brazilian sugarcane bagasse: energy and non-energy consumption. Biomass Bioenergy 46:564-573

18. Costa SM, Mazzola PG, Silva JCAR, Pahl R, Pessoa A, Jr (2013) Use of sugar cane straw as a source of cellulose for textile fiber production. Ind Crops Prod 42:189-194

19. Moraes SM, Junqueira TL, Pavanello LG, Cavalett $O$, Mantelatto $P E$, Bonomi A, Zaiat M (2014) Anaerobic digestion of vinasse from sugarcane 
biorefineries in Brazil from energy, environmental, and economic perspectives. Profit or Appl Energy 113:825-835

20. Virtual mill. In: [http://www.unica.com.br/virtual-mill/]

21. Sarkar N, Ghosh SK, Bannerjee S, Aikat K (2012) Bioethanol production from agricultural wastes: an overview. Renew Energy 37:19-27

22. Christofoletti CA, Escher JP, Correia JE, Marinho JFU, Fontanelli CS (2013) Sugarcane vinasse: environmental implications of its use. Waste Manag 33:2752-2761

23. Statistics. In: [http://www.abiove.org.br/site/index.php?page=statistics\& area $=$ MTAtMiOx]

24. Paradelo R, Models AB, Barral MT (2013) Evolution of organic matter during the mesophilic composting of lignocellulosic winery wastes. J Environ Manage 116:18-26

25. Satyanarayana KG, Arizaga GGC, Wypych F (2009) Biodegradable composites based on lignocellulosic fibers - an overview. Prog Polym Sci 34:982-1021

26. Guedes RE, Cruz F, De A, De Lima MC, Sant'Ana LD, Castro RN, Mendes MF (2014) Detoxification of Jatropha curcas seed cake using chemical treatment: analysis with a central composite rotatable design. Ind Crops Prod 52:537-543

27. Poh PE, Yong W-J, Chong MF (2010) Palm oil mill effluent (POME) characteristic in high crop season and the applicability of high- rate anaerobic bioreactors for the treatment of POME. Ind Eng Chem Res 49:11732-11740

28. Yacob S, Hassan MA, Shirai Y, Wakisaka M, Subash S (2005) Baseline study of methane emission from anaerobic ponds of palm oil mill effluent treatment. Sci Total Environ 366:187-196

29. Zakaria MR, Ariffin H, Johar NAM, Abd-Aziz S, Nishida H, Shirai Y, Hassan MA (2010) Biosynthesis and characterization of poly(3-hydroxybutyrate-co-3hydroxybutyrate) copolymer from wild type Comamonas sp. EB172. Polym Degrad Stab 95:1382-1386

30. Quispe CAG, Coronado CJR, Carvalho JA, Jr (2013) Glycerol: production, consumption, prices, characterization and new trends in combustion. Renewable Sustainable Energy Rev 27:475-493

31. Top value-added chemicals from biomass - vol. I. In: [ http://www1.eere. energy.gov/biomass/pdfs/35523.pdf]

32. Bio-succinic acid. In:[http://www.myriant.com/products/bio-succinic-acid.cfm]

33. In: The chemical industry [http://www.abiquim.org.br/pdf/indQuimica/ AlndustriaQuimica-SobreSetor.pdf]

34. (2013) FAO Statistical Yearbook 2013. In. Food and Agriculture Organization of the United Nations, Rome, p 289

35. Deleplanque J, Dubois J-L, Devaux JF, Ueda W (2010) Production of acrolein and acrylic acid through dehydration and oxydehydration of glycerol with mixed oxide catalysts. Catal Today 157:351-358

36. Tong $X, M a$ Y, Li Y (2011) Biomass into chemicals: conversion of sugars to furan derivatives by catalytic processes. Appl Catal, A 385:1-13

37. Gallezot P (2012) Conversion of biomass to selected chemical products. Chem Soc Rev 41:1538-1558

38. Bozell JJ, Petersen GR (2010) Technology development for the production of biobased products from biorefinery carbohydrates - the US Department of Energy's Top 10 revisited. Green Chem 12:539-554

39. Mota CJA, Da Silva CXA, Rosenbach N, Jr, Costa J, Da Silva F (2010) Glycerin derivatives as fuel additives: the addition of glycerol/acetone ketal (solketal) in gasolines. Energy Fuels 24:2733-2736

40. Vinardell MP, Ugartondo V, Mitjans M (2008) Potential applications of antioxidant lignins from different sources. Ind Crops Prod 27:220-223

41. Ali MF, El Ali BM, Speight JG (2005) Handbook of industrial chemistry organic chemistry. McGraw-Hill, New York

42. Nakashima K, Yamagushi K, Tanigushi N, Arai S, Uamada R, Katahira S, lashida N, Takahashi H, Ogino C, Kindo A (2011) Direct bioethanol production from cellulose by the combination of cellulase-displaying yeast and ionic liquid pretreatment. Green Chem 13:2948-2953

43. Horáček J, Homola F, Kubičková I, Kubička D (2012) Lignin to liquids over sulfided catalysts. Catal Today 179:191-198

44. Akay G, Jordan CA (2011) Gasification of fuel cane bagasse in a downdraft gasifier: influence of lignocellulosic composition and fuel particle size on syngas composition and yield. Energy Fuels 25:2274-2283

45. Hocking MB (2005) Handbook of chemical technology and pollution control. Academic Press, San Diego

46. Climent MJ, Corma A, Iborra S (2011) Heterogeneous catalysts for the one-pot synthesis of chemicals and fine chemicals. Chem Rev 111:1072-1133
47. Green chemistry in Brazil: 2010-2030. In: [http://www.cgee.org.br/busca/ ConsultaProdutoNcomTopo.php?f=1\&idProduto=6528]

48. Chemical products. In: [http://canais.abiquim.org.br/braz_new/Default.aspx? lang=en]

49. Ethanol, alcoholchemistry and biorefineries. In: [http://www.bndes.gov.br/ SiteBNDES/export/sites/default/bndes_pt/Galerias/Arquivos/conhecimento/ bnset/set2501.pdf]

50. Bioenergy. In: [http://www.fapesp.br/en/472]

51. Programs. In: [http://www.finep.gov.br/pagina.asp?pag=programas_paiss]

52. Operation areas. In: [http://www.bndes.gov.br/SiteBNDES/bndes/bndes_en/ Institucional/Financial_Support/operation_areas.html]

53. I'm green. In: [http://www.braskem.com.br/site.aspx/plastic-green]

54. Press. In: [http://graalbio.com/graalbio/wp-content/uploads/2012/02/ First_cellulosic-ethanol_plant.pdf]

55. Virmond E, De Sena RF, Albrecht W, Althoff CA, Moreira RFPM (2012) Characterisation of agroindustrial solid residues as biofuels and potential application in thermochemical processes. Waste Manag 32:1952-1961

56. Biofuels production. In: [http://www.petrobras.com.br/en/our-activities/ performance-areas/biofuel-production/]

57. Centers. In: [http://www.ipt.br/en/technology_centers/CT-FLORESTA]

\section{doi:10.1186/s40538-014-0013-1}

Cite this article as: Vaz: A renewable chemistry linked to the Brazilian biofuel production. Chemical and Biological Technologies in Agriculture 2014 1:13.

\section{Submit your manuscript to a SpringerOpen ${ }^{\odot}$ journal and benefit from:}

- Convenient online submission

- Rigorous peer review

- Immediate publication on acceptance

- Open access: articles freely available online

- High visibility within the field

- Retaining the copyright to your article

Submit your next manuscript at $\gg$ springeropen.com 